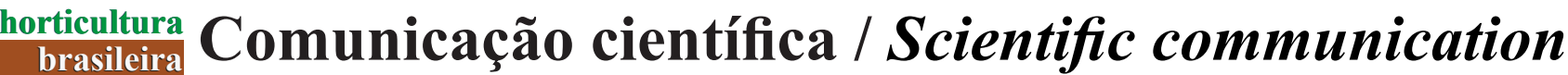

ECHER MM; DALASTRA GM;HACHMANN TL; KLOSOWSKI ES; GUIMARÃES VF. 2015. Agronomic performances of Pak Choi grown with different soil cover. Horticultura Brasileira 33: 261-266. DOI - http://dx.doi.org/10.1590/S0102-053620150000200020

\section{Agronomic performances of Pak Choi grown with different soil cover}

\author{
Márcia M Echer; Graciela M Dalastra; Tiago L Hachmann; Elcio S Klosowski; Vandeir F Guimarães \\ UNIOESTE, CCA, R. Pernambuco 1777, 85960-000 Marechal Cândido Rondon-PR; mmecher@bol.com.br; gradalastra@hotmail.com; \\ tiagohach@gmail.com; elciosk1@yahoo.com.br; vandeirfg@yahoo.com.br
}

\begin{abstract}
An important aspect in the cultivation of vegetables is the quality of the product to be marketed, free from dirt and damage and the practice of mulching could be an option, but there is scarse information. The aim of this study was to evaluate the influence of mulching on the production traits of three cultivars of Pak Choi. The experiment was set up during March to May 2013 using a split plot randomized block design, with four replications. Soil cover treatments (white agrotextile, black agrotextile, black plastic, silver plastic, tifton straw and bare soil) were arranged in the plots, and three cultivars of Pak Choi (Green Pak Choi, White Pak Choi and Chingensai Natsu Shomi) in subplots. Height and diameter of shoots, number of leaves, fresh weight of the head and petiole, base diameter, dry weight of stem, petiole, and leaf were evaluated thirty-five days after transplantation. The total dry weight and leaf area were measured, and then we estimated the yield. There was a significant effect of soil cover and cultivar. In general, the cover with synthetic materials showed higher values on production of Pak Choi. The cultivar White Pak Choi was better adapted to the growing conditions, with an average yield of $57.78 \mathrm{t} / \mathrm{ha}$.
\end{abstract}

Keywords: Brassica campestris var. chinensis, mulching, non-wovenfabric, polyethylene.

\section{RESUMO}

Desempenho agronômico de Pak Choi cultivado com diferentes coberturas do solo

Um aspecto importante no cultivo das hortaliças é a qualidade do produto a ser comercializado, livre de sujeira e danos e a prática de cobertura do solo poderia ser uma opção, mas as informações são escassas. O objetivo desse estudo foi avaliar a influência de coberturas de solo sobre as características de produção de três cultivares de Pak Choi. O experimento foi conduzido de março a maio 2013 usando o delineamento de blocos ao acaso, com quatro repetições. Os tratamentos de cobertura do solo (tecido não tecido branco, tecido não tecido preto, plástico preto, plástico prata, palha de tifton e solo nu) foram dispostos nas parcelas, e as três cultivares de Pak Choi (Green Pak Choi, White Pak Choi e Chingensai Natsu Shomi) dispostas nas subparcelas. Altura e diâmetro da parte aérea, número de folhas, massa fresca da cabeça e pecíolo, diâmetro do colo, massa seca de caule, pecíolo, e folhas foram avaliados 35 dias após o transplante. Foram medidos a massa total da parte aérea e o rendimento. Houve um efeito significativo da cobertura do solo e cultivar. Em geral, a cobertura com materiais sintéticos mostrou valores mais elevados na produção de Pak Choi. A cultivar White Pak Choi foi melhor adaptada às condições de cultivo com um rendimento médio de 57,78 t/ha.

Palavras-chave: Brassica campestris var. chinensis, mulching, agrotêxtil, polietileno.

(Recebido para publicação em 4 de dezembro de 2013; aceito em 18 de dezembro de 2014) (Received on December 4, 2013; accepted on December 18, 2014)

$\mathrm{P}$ ak Choi cabbage (Brassica campestris var. chinensis), also known as Chinese white cabbage, is a specie of light or dark green leaves forming a kind of rosette, with succulent light green or white petioles (Reghin et al., 2002a). This annual vegetable has optimal growth and development at temperatures between 15 and $20^{\circ} \mathrm{C}$ (Maroto, 1995). The cultivation of this vegetable is not yet widespread in the world, and it is cultivated mainly in Asia. However, it is an attractive vegetable of easy commercialization, consumed especially in Oriental restaurants (Alves et al., 2003). This type of product is rarely found in supermarket shelfs, opening opportunities for small producers.

An important aspect in the cultivation of vegetables, especially leafy ones, is the quality of the product to be marketed. It must have good appearance, free from dirt and damage. In this sense, the practice of mulching is an option to increase the yield and quality of this vegetable (Reghin et al., 2002a). This practice is widespread among vegetable producers and aims to avoid direct contact of lower leaves with the ground, which under higher humidity conditions spoil quickly.

Both synthetic and organic materials (crop residues) can be used for soil cover.
Organic materials are traditionally used, especially in 'low-tech' crops (Mitchell et al., 2004). The soil cover with crop residues is made in a thick enough for that the sunlight is partially blocked, so as to inhibit the germination of weeds in the soil.

Otherwise, mulching with plastic has been used worldwide for over thirty years (Mitchell et al., 2004) and it has provided increases in growth and yield in many vegetables. The use of plastic films in agriculture has benefits such as increased productivity, early yield, less soil compaction, which occurs by the action of water droplets, increased soil temperature, soil moisture 
conservation, reduced evaporation, low incidence of weeds and diseases, and reduced loss of nutrients by leaching (Sampaio \& Araújo, 2001). The color of the material is a determining factor in the microclimate of the crop canopy. Black plastic absorbs $91 \%$ of incident radiation, and thus is commonly used in cultures at lower temperatures, since it provides increases of up to $2.8^{\circ} \mathrm{C}$ compared to bare soil (Moura et al., 2009).

Studies developed with tomato showed that although the production in the first cycle provided by soils covered by plant material is lower, the production in subsequent cycles tends to increase under such coverage when compared to the soil covered with black plastic (Chellemi et al., 1999). Plant residues may contribute with considerable reserves of nutrients, whose availability depends on the rainfall and the carbon/nitrogen ratio, and by reducing leaching of nutrients and soil compaction (Rosolem et al., 2003).

Other material introduced into crops is the double-sided plastic, black and silver. This plastic combines the advantages of black plastic, increasing soil temperature, with the reflection characteristics of silver plastic on the management of insects and diseases (Mitchel et al., 2004). A study conducted by Verdial et al. (2000) reported a higher yield and better quality of plants of lettuce cultivar Lucy Brown in cultivation on double-sided plastic. Mulching with double-sided plastic (black/silver) and rice husk promoted a better development of lettuce plants compared with the bare soil and cultivated directly on Brachiaria in Northern Brazil (Ferreira et al., 2009).

Other different materials for soil cover are also used. Ferreira (2001) using black plastic and carnauba straw observed lower soil temperature compared with bare soil to the melon cultivation. Costa et al. (2002) observed a $25 \%$ increase in yield of cantaloupe using silver and yellow plastic compared to bare soil. In addition, Olinik et al. (2011), testing zucchini cultivars obtained higher yield when grown on silver polyethylene, against the black polyethylene, black polypropylene (NWF), rice husk and bare soil.

An alternative material, with lower cost and being spread in the cultivation of vegetables, is the agrotextile, row cover, or polypropylene. According to Reghin et al. (2002b), the use of black agrotextile provided the highest yield of Veneza Roxa lettuce, compared to rice straw mulch (153.68 and $127.71 \mathrm{~g}$, respectively).

Under brazilian growing conditions, studies show that mulching materials promoted lower temperature range in the soil than synthetic materials, with values of $2.7^{\circ} \mathrm{C}$ against $4.3^{\circ} \mathrm{C}$ amplitude under black plastic (Araújo, 2011). According to Wien \& Minotti (1987), the soil cover increases the availability and absorption of nutrients. Surveys conducted by these authors found increases in the availability of nitrogen, phosphorus, potassium, calcium, magnesium and boron in the soil when using plant mulching.

The objective of this study was to evaluate the influence of different soil covers on production of three cultivars of Pak Choi.

\section{MATERIAL AND METHODS}

The experiment was conducted during March to May 2013 at the experimental farm of Universidade Estadual do Oeste do Paraná, Marechal Cândido Rondon, Paraná state, Brazil, under field conditions. The climate was classified as Cfa, subtropical, according to Köppen classification. The maximum, minimum and average air temperature during the experiment was $31.5^{\circ} \mathrm{C}$, $5.3^{\circ} \mathrm{C}$ and $19.8^{\circ} \mathrm{C}$, respectively. The precipitation during the experiment was of $248 \mathrm{~mm}$.

Chemical analysis of an Oxisol (640 $\mathrm{g} / \mathrm{kg}$ clay) collected at the depth of 0-20 cm, showed: $\mathrm{pH}\left(\mathrm{CaCl}_{2}\right)=6.0$; Organic Matter $=17.8 \mathrm{~g} / \mathrm{dm}^{3} ; \mathrm{P}=32.6 \mathrm{mg} / \mathrm{dm}^{3}$; $\mathrm{K}=0.86 \mathrm{cmol}_{\mathrm{c} /} \mathrm{dm}^{3} ; \mathrm{Ca}=6.9 \mathrm{cmol}_{\mathrm{c} /} \mathrm{dm}^{3}$; $\mathrm{Mg}^{2+}=3.2 \mathrm{cmol}_{\mathrm{c} /} \mathrm{dm}^{3} ; \mathrm{T}=10.9 \mathrm{cmol}_{\mathrm{c} /} \mathrm{dm}^{3}$ and basis saturation $(\%)=74.5$.

The experiment was conducted in a split plot randomized block design, with four replications. In the plots the soil cover treatments were arranged: white row cover (white agrotextile, weight of $25 \mathrm{~g} / \mathrm{m}^{2}$ ), black row cover (black agrotextile, weight of $25 \mathrm{~g} / \mathrm{m}^{2}$ ), black plastic (black polyethylene, 25 microns), double-sided plastic black/ silver (black/silver polyethylene, 25 microns), tifton straw and bare soil. In the subplots, three cultivars of Pak Choi (Green Pak Choi, White Pak Choi and Chingensai Natsu Shomi) were assigned.

The seedlings were grown in polyethylene trays of 200 cells containing commercial substrate under protected cultivation. The transplanting occurred when the seedlings had 4-5 mature leaves (30 days after sowing). The fertilizer was applied according to Trani et al. (1997) for lettuce crops. Irrigation was carried out by spraying, according to FAO standard evapotranspiration (Allen et al., 1998). After the planting fertilization $(440 \mathrm{~kg} /$ ha $\mathrm{N}, 300 \mathrm{~kg} / \mathrm{ha} \mathrm{P}_{2} \mathrm{O}_{5}$ and $120 \mathrm{~kg} / \mathrm{ha}$ $\mathrm{K}_{2} \mathrm{O}$ ) and incorporation of fertilizers, the plots were covered with soil cover materials, which were fixed with metal clips at the ends of the plots and then were opened holes in the spacing determined. Fertilization was divided into three times (at 7, 14 and 21 days after transplantation), in a total of 90 $\mathrm{kg} / \mathrm{haN}$.

The experimental plots consisted of 48 plants, and each subplot consisted of 16 plants, in four rows, spaced 30 $\mathrm{cm}$ between plants and between rows. The working area was defined as the two central rows, and harvested a total of four plants per subplot.

Plants were harvested 35 days after transplanting, at the maximum vegetative development. These were evaluated in the field for the height and diameter of the plant, measuring up the four central plants of each plot, with the aid of a graduated ruler. Then these plants were collected and taken to the laboratory, where, with a digital caliper, was measured the diameter of the base, measured the total head weight, of fresh leaves and of petioles and counting the number of leaves. After, the different parts of the plants were placed in paper bags and dried in a forced air oven at $65 \pm 5^{\circ} \mathrm{C}$, until constant weight. Subsequently, the plant parts 
were weighed on a precision scale and calculated the total dry weight.

Leaf area was estimated by the method proposed by Benincasa (2003). Sub-samples were taken from leaves, from which, leaf discs were taken with known area. Subsequently, with the values of dry weight of the discs and of leaves the leaf area was calculated. Yield ( $\mathrm{t} / \mathrm{ha}$ ) was estimated based on the fresh weight of the four plants evaluated at harvest time.

The analysis of variance was run by the statistical program SISVAR (Ferreira, 2011), and the means compared by Tukey test $(\mathrm{p}<0.05)$.

\section{RESULTS AND DISCUSSION}

A significant interaction was detected between soil cover and cultivars of Pak Choi for fresh weight of the head, fresh and dry petiole weight and yield. For other variables there was no interaction; so, the factors were studied separately.
Cultivar White Pak Choi showed higher values of fresh weight of the head when grown on silver plastic soil cover compared to bare soil and white row cover (Table 1). Similar results were registered by Cantu et al. (2013), when evaluated with arugula growing on different mulching. These authors showed higher production of fresh matter when the crop was cultivated under double-sided black and white plastic, and black plastic in relation to the growing without cover. This indicates that the use of soil cover has benefits over soil devoid of any kind of cover. The other cultivars were not affected by soil cover.

Mulching with plastic materials promoted higher fresh weight for White Pak Choi. This is probably due to increased soil temperature when using these materials resulting in improved uptake of water and nutrients by the roots in these conditions, thus favoring the development and accumulation of weight by the plants. According to Araújo (2011), the temperature in the surface layer of soil covered with black or transparent film increases considerably compared to bare soil. The use of plastics reduces the latent heat flux and increases the sensitive heat flux to soil, providing increased heating as compared to other types of coverage (Araújo et al., 2003).

Regarding soil coverages, for black row cover and Tifton straw, cultivars White Pak Choi and Chingensai Natsu Shomi had higher fresh weight of the head, the latter did not differ from the cultivar Green Pak Choi. For silver and black plastics, the cultivar White Pak Choi resulted in higher values for this variable. For soil cover with white row cover and bare soil, no difference was observed with respect to cultivars.

The results of fresh weight are lower than found by Dartora et al. (2013) when cultivated Canton Pak Choi in protected ambient, and obtained fresh weight of shoots of $720.6 \mathrm{~g}$ per plant when used the highest level of nitrogen $(195 \mathrm{~kg} /$

Table 1. Fresh weight of head, fresh weight of petioles, dry weight of petioles per plant and yield of three cultivars of Pak Choi according to soil cover (massa fresca da cabeça, massa fresca dos pecíolos, massa seca dos pecíolos e produtividade de três cultivares de Pak Choi em função da cobertura do solo). Marechal Cândido Rondon, Unioeste, 2013.

\begin{tabular}{|c|c|c|c|c|c|c|}
\hline \multirow[b]{2}{*}{ Cover } & \multicolumn{3}{|c|}{ Fresh weight of head (g/plant) } & \multicolumn{3}{|c|}{ Fresh weight of petioles (g/plant) } \\
\hline & $\begin{array}{l}\text { Green Pak } \\
\text { Choi }\end{array}$ & $\begin{array}{l}\text { White Pak } \\
\text { Choi }\end{array}$ & $\begin{array}{l}\text { Chingensai } \\
\text { Natsu Shomi }\end{array}$ & $\begin{array}{c}\text { Green } \\
\text { Pak Choi }\end{array}$ & $\begin{array}{l}\text { White Pak } \\
\text { Choi }\end{array}$ & $\begin{array}{c}\text { Chingensai Natsu } \\
\text { Shomi }\end{array}$ \\
\hline White row cover & $362.45 \mathrm{aA}$ & $330.42 \mathrm{bA}$ & $374.14 \mathrm{aA}$ & $248.41 \mathrm{aA}$ & $203.92 \mathrm{bA}$ & $237.27 \mathrm{aA}$ \\
\hline Black row cover & $280.22 \mathrm{aB}$ & $465.92 \mathrm{abA}$ & $367.11 \mathrm{aAB}$ & $184.14 \mathrm{aB}$ & $287.59 \mathrm{abA}$ & $244.38 \mathrm{aAB}$ \\
\hline Silver plastic & $269.26 \mathrm{aB}$ & $520.03 \mathrm{aA}$ & $390.96 \mathrm{aB}$ & $173.08 \mathrm{aB}$ & $323.27 \mathrm{aA}$ & $256.64 \mathrm{aAB}$ \\
\hline Black plastic & $261.16 \mathrm{aB}$ & 474.19abA & $346.28 \mathrm{aB}$ & $171.01 \mathrm{aB}$ & $299.80 \mathrm{abA}$ & $219.43 \mathrm{aAB}$ \\
\hline Tifton straw & $262.65 \mathrm{aB}$ & 405.78abA & $316.11 \mathrm{aAB}$ & $169.03 \mathrm{aA}$ & $245.57 \mathrm{abA}$ & $202.83 \mathrm{aA}$ \\
\hline Bare soil & $333.28 \mathrm{aA}$ & $358.86 \mathrm{bA}$ & $336.92 \mathrm{aA}$ & $225.13 \mathrm{aA}$ & $214.27 \mathrm{abA}$ & $216.97 \mathrm{aA}$ \\
\hline CV plot(\%) & \multicolumn{3}{|c|}{18.36} & \multicolumn{3}{|c|}{21.30} \\
\hline \multirow[t]{2}{*}{ CV subplot(\%) } & \multicolumn{3}{|c|}{21.67} & \multicolumn{3}{|c|}{23.62} \\
\hline & \multicolumn{3}{|c|}{ Dry weight of petioles (g/plant) } & \multicolumn{3}{|c|}{ Yield (t/ha) } \\
\hline White row cover & $6.56 \mathrm{aA}$ & $5.86 \mathrm{aA}$ & $6.03 \mathrm{aA}$ & $40.27 \mathrm{aA}$ & $36.71 \mathrm{bA}$ & $41.57 \mathrm{aA}$ \\
\hline Black row cover & $4.73 \mathrm{abB}$ & $7.00 \mathrm{aA}$ & $5.91 \mathrm{aAB}$ & $31.13 \mathrm{aB}$ & $51.76 \mathrm{abA}$ & $40.79 \mathrm{aAB}$ \\
\hline Silver plastic & $4.75 \mathrm{abB}$ & $7.75 \mathrm{aA}$ & $5.27 \mathrm{aB}$ & $29.91 \mathrm{aB}$ & $57.78 \mathrm{aA}$ & $43.43 \mathrm{aB}$ \\
\hline Black plastic & $4.30 \mathrm{abB}$ & $7.13 \mathrm{aA}$ & $4.65 \mathrm{aB}$ & $29.01 \mathrm{aB}$ & $52.68 \mathrm{abA}$ & $38.47 \mathrm{aB}$ \\
\hline Tifton straw & $3.86 \mathrm{bB}$ & $6.20 \mathrm{aA}$ & $4.50 \mathrm{aAB}$ & $29.18 \mathrm{aB}$ & 45.08abA & $35.12 \mathrm{aAB}$ \\
\hline Bare soil & $5.64 \mathrm{abA}$ & $5.54 \mathrm{aA}$ & $5.24 \mathrm{aA}$ & $37.03 \mathrm{aA}$ & $39.87 \mathrm{bA}$ & $37.43 \mathrm{aA}$ \\
\hline CV plot(\%) & \multicolumn{3}{|c|}{19.39} & \multicolumn{3}{|c|}{18.36} \\
\hline CV subplot(\%) & \multicolumn{3}{|c|}{19.30} & \multicolumn{3}{|c|}{21.67} \\
\hline
\end{tabular}

*Means followed by the same uppercase letter in the row and lowercase letter in the column are not significantly different at $5 \%$ probability by Tukey test (médias seguidas da mesma letra maiúscula na linha e letra minúscula na coluna, não diferem entre si pelo teste de Tukey a 5\%). 
Table 2. Height (HEI), plant diameter (PD), basal diameter (BD), fresh weight of leaves (FWL), dry weight of leaves (DWL), total dry weight (TDW), stem dry weight (SDW), leaf area (LA) and number of leaves (NL) per plant, of three cultivars of pak choi according to soil cover \{altura (HEI), diâmetro da planta (PD), diâmetro basal (BD) massa fresca das folhas (FWL), massa seca das folhas (DWL), massa seca total (TDW), massa seca dos pecíolos (SDW), area foliar (LA) e número de folhas (NL) por planta, de três cultivares de pak choi em função da cobertura do solo\}. Marechal Cândido Rondon, Unioeste, 2013.

\begin{tabular}{|c|c|c|c|c|c|c|c|c|c|}
\hline \multirow{2}{*}{ Cultivar } & HEI & PD & BD & FWL & DWL & TDW & SDW & \multirow{2}{*}{$\begin{array}{c}\mathbf{L A} \\
\left(\mathbf{d m}^{2}\right)\end{array}$} & \multirow{2}{*}{ NL } \\
\hline & \multicolumn{3}{|c|}{$(\mathrm{cm})$} & \multicolumn{4}{|c|}{ (g) } & & \\
\hline White Pak Choi & $30.77 \mathrm{a}$ & $37.92 a$ & $8.28 \mathrm{a}$ & $161.21 \mathrm{a}$ & $10.28 \mathrm{a}$ & $19.12 \mathrm{a}$ & $2.24 \mathrm{a}$ & $363.77 \mathrm{a}$ & $16.12 b$ \\
\hline Ching. Natsu Shomi & $22.63 b$ & $34.77 b$ & $7.85 \mathrm{a}$ & $123.35 b$ & $7.64 b$ & $15.23 b$ & $2.31 \mathrm{a}$ & $245.08 b$ & $18.68 \mathrm{a}$ \\
\hline Green Pak Choi & $23.15 b$ & $33.44 \mathrm{~b}$ & $8.27 \mathrm{a}$ & $97.94 \mathrm{c}$ & $6.37 \mathrm{c}$ & $13.11 \mathrm{c}$ & $1.76 \mathrm{~b}$ & $212.65 \mathrm{c}$ & $16.27 \mathrm{~b}$ \\
\hline CV plot (\%) & 8.06 & 4.51 & 10.20 & 16.56 & 17.92 & 16.06 & 32.35 & 19.68 & 12.34 \\
\hline
\end{tabular}

*Means followed by the same letter are not significantly different at $5 \%$ probability by Tukey test (médias seguidas da mesma letra, na coluna, não diferem entre si pelo teste de Tukey a 5\%).

ha). This demonstrates that species are subjected to interference of both growing environment and management applied.

Greater fresh weight of petioles was verified for White Pak Choi, when grown on silver plastic mulching, compared with white row cover, with no differences among the other materials (Table 1). For soil coverages with black agrotextiles, silver and black plastics, the cultivar White Pak Choi had higher fresh weight of petioles than Green Pak Choi, being Chingensai Natsu Shomi intermediate. For the other types of soil cover used (white row cover, Tifton straw and bare soil), the fresh weight of petioles was not different between cultivars. Hachmann et al. (2010), examinating Chinguensai Choyou grown on different soil covers and floating blanket in western Paraná, observed that plants grown on black plastic had higher fresh weight of petioles.

The fresh weight of petioles is an important indicator in the choice of cultivars. Table 1 shows that the cultivar Green Pak Choi has up to $68 \%$ of the total weight of the plant composed of stems, while the cultivar White Pak Choi has at most $63 \%$ of the total plant weight represented by petioles. Genotypes with greater weight of petioles are best employed in the preparation of dishes using that part of the plant. This genetic material can replace the Chinese cabbage in stews and in yakissoba, with advantage of being more crunchy, juicy and tasty (Sakama, 2013).

The cultivar Green Pak Choi accumulated higher dry weight of petioles when grown on white agrotextiles, compared to Tifton straw (Table 1). The other cultivars showed no effect of soil cover for this characteristic. However, even without statistical difference, it is observed that for the cultivar White Pak Choi, higher values of dry weight were achieved in the cultivation on silver plastic.

Silvered films reflect almost all the energy radiated by the sun. In periods of low light or in denser plantings, the energy reflected by silver films may favor the photosynthesis of leaves located at the bottom of the plant canopy and thus contribute to the production of photoassimilates, which compose the plant dry weight (Sampaio \& Araújo, 2001).

With regard to the cultivars, crops on black row cover and Tifton straw presented higher dry weight of petioles for White Pak Choi than Green Pak Choi. Chingensai Natsu Shomi had intermediate performance among cultivars for this characteristic (Table 1).

The yield of White Pak Choi cultivar was higher when cultivated on silver plastic than on white row cover and bare soil. For the other cultivars there was no effect of soil cover on crop yield (Table 1). This increased yield is due to changes in soil and air temperature near the coverage, water balance and nutrient availability. The plastic coverage conserves moisture in the layer near the soil surface, causing the roots to concentrate on the warmer and more fertile layer, which generates a better absorption of nutrients and earlier development of plant. (Araújo, 2011). Similar results were obtained by Ferreira et al. (2009), working with three lettuce cultivars in different soil covers, which achieved a higher productivity when the cultures were grown on silver plastic and rice husk, compared to bare soil.

With respect to the materials of soil cover, the black row cover and Tifton straw provided higher yields for the cultivars White Pak Choi and Chingensai Natsu Shomi, but the latter was not different from cultivar Green Pak Choi. The difference between cultivars is inherent to the genetic material and its interaction with the environment conditions.

The highest yield obtained in this experiment was $57.78 \mathrm{~kg} / \mathrm{ha}$, which is far below the reported by Dartora et al. (2013) who obtained yield of 112 $\mathrm{t} / \mathrm{ha}$ when applied $195 \mathrm{~kg} / \mathrm{ha}$ nitrogen, indicating the importance of fertilization for the crop.

The height and diameter of the plants was higher for the cultivar White Pak Choi (Table 2). The cultivar White Pak Choi also had higher fresh and dry weight of leaves, total dry weight and leaf area than the cultivar Chingensai Natsu Shomi, which in turn showed higher values for these variables compared to the cultivar Green Pak Choi. The basal diameter was not significantly different between the cultivars. For height and plant diameter and basal diameter, Feltrim et al. (2003), testing different plant densities with and without application of nitrogen in the crop of Pak Choi, hybrid Chouyou, observed mean values of $21.57,27$ 
and $7.17 \mathrm{~cm}$ respectively, lower than the results found herein. Dartora et al. (2013) evaluated the influence of different nitrogen levels on growth and productivity of Canton Pak Choi and obtained the highest plant height (29.48 $\mathrm{cm})$ at a level of $140 \mathrm{~kg} / \mathrm{ha}$.

Plant height and diameter, basal diameter, leaf fresh weight, and number of leaves are variables with most importance, since they indicate the adaptability of the material in relation to the environment. The variation in the results obtained is justified because these characteristics are related to genetics of each cultivar, but may also be influenced by the cultivation environment and may result in morphological and physiological changes of plants (Hermes et al., 2001).

The stem dry weight was lower for the cultivar Green Pak Choi. Regarding the number of leaves, the prominent cultivar was the Chinguensai Natsu Shomi. Feltrim et al. (2003) for this component, observed 17.85 leaves when plants were fertilized with $40 \mathrm{~kg} /$ ha nitrogen, indicating that this variable varies with cultivar, time, place and culture conditions.

During the cultivation period, we observed early tasseling in the cultivar White Pak Choi. This is a characteristic of the cultivar, which is better suited to crops in warmer conditions, and tends to bloom early under colder conditions (Rokewood, 2012). This earliness with which the material entered the reproductive phase can be justified by the low air temperature recorded during the experiment. During most of the crop cycle the minimum air temperatures were below $15^{\circ} \mathrm{C}$, resulting in the tasseling of the cultivar White Pak Choi. This may also explain the higher plant height observed for this cultivar, showing that there was an increase in stem for the emergence of the flower tassel.

The soil cover is an important practice in the cultivation of Pak Choi, yielding 44.91\% more than the cultivation without mulching. The cultivar White Pak Choi obtained the highest yield (57.78 t/ha) under the growth conditions of the experiment. In general, the soil cover with synthetic materials provided higher values of productive characteristics of Pak Choi.

Comparing the results obtained in this experiment with other studies, it is evidenced that vegetable species have different production responses in relation to the different materials for soil cover, which is related to the ability of species to adapt to the changes performed in the environment of cultivation. Thus, it is necessary to conduct further studies to see how each species will behave on the use of mulching materials in different seasons of the year and may indicate an ideal material to be used in each season.

\section{REFERENCES}

ALLEN RG; PEREIRA LS; RAES D; SMITH M. 1998. Crop evapotranspiration: guidelines for computing crop water requirements. Rome: FAO, 300p.

ALVES BL; FELTRIM AL; CECÍLIO FILHO AB. 2003. Produção de pak choi sob diferentes sistemas de cultivo. In: CONGRESSO BRASILEIRO DE OLERICULTURA, 43. Anais eletrônicos... Recife: ABH. Disponível em: http://www.abhorticultura. com.br/biblioteca/arquivos/Download/ Biblioteca/44_252.pdAcessado em 21 de junho de 2013.

ARAÚJO AP. 2011. Produção, qualidade e efeitos microclimáticos no cultivo de tomate industrial em diferentes coberturas do solo no município de Baraúna-RN. Mossoró: UFERSA. 102p (Tese doutorado).

ARAÚJO AP; NEGREIROS MZ; LEITÃO MMVBR; PEDROSA JF; BEZERRA NETO F; ESPÍNOLA SOBRINHO J; FERREIRA RLF; NOGUEIRA ICC. 2003. Rendimento de melão amarelo cultivado em diferentes tipos de cobertura do solo e métodos de plantio. Horticultura Brasileira 21: 123-126.

BENINCASA MMP. 2003. Análise de crescimento de plantas: noções básicas. $2^{\mathrm{a}}$ ed. Jaboticabal: FUNEP. 42p.

CANTU RR; GOTO R; JUNGLAUS RW; GONZATTO R; CUNHA AR. 2013. Uso de malhas pigmentadas e mulching em túneis para cultivo de rúcula: efeito no ambiente e nas plantas modelo. Ciência Rural 43: 810-815.

CHELLEMI DO; RHOADS FM; OLSON SM; RICH JR; MURRAY D; SYLVIA DM. 1999. An alternative, low-input production system for fresh market tomatoes. American Journal of Alternative Agriculture 14: 59-68,

COSTA FA; MEDEIROS JF; NEGREIROS MZ; BEZERRA NETO F; PÔRTO DR; CHAVES SWP; DANTAS KN. 2002. Rendimento de melão cantaloupe em diferentes coberturas de solo e lâminas de irrigação. Caatinga 15: 49-55.

DARTORA J; GUIMARÃES VF; ECHER MM;
PAULETTI DR; MARINID. 2013. Análise de crescimento e produtividade do pak choi cultivado sob diferentes doses de nitrogênio. Ceres 60: 485-504.

FELTRIM AL; REGHIN MY; VINNE J. 2003. Cultivo do pak choi em diferentes densidades de plantas com e sem aplicação de nitrogênio. Ciência Exatas e da Terra, Agrárias e Engenharia 9: 7-13.

FERREIRADF. 2011. Sisvar: a computer statistical analysis system. Ciência e Agrotecnologia: 35 : 1039-1042.

FERREIRA RLF. 2001. Produção e qualidade de melão cultivado sob condições climáticas resultantes de diferentes coberturas de solo e métodos de plantio. Mossoró: ESAM. 63p. (Dissertação mestrado).

FERREIRA RLF; ARAÚJO NETO SE; SILVA SS; ABUD EA; REZENDE MIFL; KUSDRA JF. 2009. Combinações entre cultivares, ambientes, preparo e cobertura do solo em características agronômicas de alface. Horticultura Brasileira 27: 383-388.

HACHMANN TL; ECHER MM; SCHNEIDER RP; MIRANDA AM; HARTMANN MA. 2010. Características produtivas do Pak Choi cultivado sob diferentes mulchings e sob manta flutuante. Horticultura Brasileira 28: S1714-S1720.

HERMES CC; MEDEIROS SLP; MANFRON PA; CARON B; POMMER SF; BIANCHI C. 2001. Emissão de folhas de alface em função de soma térmica. Revista Brasileira de Agrometeorologia 9: 269-275.

MAROTO JVB. 1995. Horticultura herbacea especial. 4. Ed. Madri: Mundi-Prensa, 611p.

MITCHEL J; SUMMERS C; MCGIFFEN M; AGUIAR J; ASLAN S; STAPLETON J. 2004. Mulches in California vegetable crop production. Publicação: 8129.

MOURAM SB; SOUZA LSB; BRAGA MB; BRANDÃO EO; CORREIAJS; CARMO JFA; SILVA FZ; SILVA TGF. 2009. Temperatura do solo cultivado com meloeiro sobre diferentes coberturas do solo no submédio São Francisco. In: XVI CONGRESSO BRASILEIRO DE METEOROLOGIA. Anais... Belo Horizonte: SBAGRO. p 269-274.

OLINIK JR; OLIVEIRA JÚNIOR A; KEPP MA; REGHIN MY. 2011. Produtividade de híbridos de abobrinha italiana cultivados sob diferentes coberturas de solo. Horticultura Brasileira 29: 130-134.

REGHIN MY; OTTO RF; VINNE J; FELTRIM AL. 2002a. Produção de repolho branco chinês (pak choi) sob proteção com "não tecido" de polipropileno. Horticultura Brasileira 20: 233-236.

REGHIN MY; PURISSIMO C; DALLA PRIA M; FELTRIM AL; FOLTRAN MA. 2002b. Técnicas de cobertura do solo e de proteção de plantas no cultivo da alface. In: CONGRESSO BRASILEIRO DE OLERICULTURA, 42. Resumos... Uberlândia: v.20, Suplemento 2. CD-ROM.

ROKEWOOD. Products: Pak Choi. Online. Disponível em: $<$ http://www.rokewood.co.uk/ pakchoi.html $>$ Consulta em 23 de junho de 2013.

ROSOLEM CA; CALONEGO JC; FOLONI 
JSS. 2003. Lixiviação de potássio da palha de espécies de cobertura de solo de acordo com a quantidade de chuva aplicada. Revista Brasileira de Ciência do Solo 27: 355-362.

SAMPAIO RA; ARAÚJO WF. 2001. Importância da cobertura plástica do solo sobre o cultivo de hortaliças. Agropecuária Técnica 22: 1-12.

SEMENTES SAKAMA, 2013. disponivel em: http://www.sementesakama.com.br/produtos/ produtos_orientais. Acesso: 22/08/2013.

TRANI EP; PASSOS FA; TAVARES M; AZEVEDO FILHO JA. 1997. In: RAIJ VB; CANTARELLA H; QUAGGIO JA; FURLANI, AMC (eds). Recomendação de adubação e calagem para o Estado de São Paulo. Campinas: Instituto Agronômico/ Fundação IAC. 147p. (IAC. Boletim Técnico 100).
VERDIAL MF; LIMA MS; MOGOR AF; GOTO R. 2000. Comportamento da alface tipo americana sob diferentes coberturas de solo. Horticultura Brasileira 18: 486-488.

WIEN HC; MINOTTI PL. 1987. Growth, yield and nutrient uptake of transplanted freshmarket tomatoes as affected by plastic mulch and initial nitrogen rate. Journal of American Society for Horticutural Science 112: 759-763 